\title{
The Management of Inclusive Schools' Curriculum in Indonesia
}

\author{
Endang Pudjiastuti Sartinah ${ }^{1, *}$ Murtadlo ${ }^{1}$ \\ ${ }^{1}$ Department of Special Education Universitas Negeri Surabaya \\ *Corresponding author. Email: endangsartinah@unesa.ac.id
}

\begin{abstract}
The 1945 Constitution and the International Call for Education ("EFA"), reiterated by UNESCO as a worldwide consensus arising from the World Education Forum in Dakar, Senegal in 2000, promoted the government's policy of providing services for all people in education. This study aims to develop a model for managing the curriculum and learning model of inclusive schools in Indonesian junior high schools. This development study was conducted in three stages: (1) an examination of the initial challenges in order to determine the requirements for building an inclusive school's curriculum management; (2) the creation of an inclusive school's curriculum management; and (3) the development of an inclusive school's curriculum management. (2) the creation step, which entailed developing a model of an inclusive school's curriculum.; (3) the assessment step, which comprised analyzing the product's efficacy, efficiency, and correctness in the form of curriculum administration in an inclusive school. Borg and Gall's development theory, as well as Thiagaradjan's, were used in this developmental investigation. According to the findings, curriculum management in inclusive schools has evolved in response to demands. Furthermore, there are four curriculum creation strategies depending on students' needs, talents, and learning content: duplication, modification, omission, and substitution.
\end{abstract}

Keywords - curriculum, management, inclusive schools.

\section{INTRODUCTION}

Education is a basic need of every human being. With education, humans can improve the welfare of their life $[1,2]$. According to National Education System Law No. 20 of 2003, education is a self aware and started planning effort to create an environment of knowledge and teaching process in which students actively develop their potency to have religious-spiritual strength, self-control, personality, intelligence, good character, including the skills required by himself, society, nation, and state. Article 31, paragraph I of the 1945 Constitution declares that every person has the right to an education. The above phrase indicates that all children in Indonesia have the same educational rights [3].

Furthermore, Article 4 paragraph 1 of Law No. $20 / 2003$ stipulates that education is conducted out in a democracy and just way that is not discriminate by protecting human rights, religious values, cultural values, and the principle of national plurality. To that end, the government published a policy in the National Education System Law number 20 of 2003 governing the National Education System, which was implemented. which in article 32 regulates special education and special services for children with special needs. Then, in The Regulation of Indonesia's Minister of National Education number 70 of 2009 [4], the implementation is regulated by providing opportunities for children with special needs to obtain education in elementary schools, junior high schools, and senior high schools in the nearest public schools. So, in addition to being able to get education in special schools, children with special needs can also obtain education in inclusive elementary school, inclusive junior, and senior high schools and can learn together with their typicallydeveloping children. Children with special needs are children who have abnormalities in physical, mental, behavioral so that to develop the maximum capacity requires extraordinary education or services related to special education $[5,6,7]$

According to Indonesia's Minister of National Education Regulation No. 70 of 2009, Inclusionary education is described as a method of education delivery that permits all children with disabilities, unique intellect, and/or skill to engage in education or learning in educational facilities alongside kids of typical development. Schools that provide inclusive education are called inclusive schools [4].[8,9,10] explain that 
schools that provide inclusive education are schools that accommodate all students in the same class.

By seeing the meaning of inclusive education, namely, children with special needs are entitled to the same education as children with typical development, the teachers in inclusive schools must be ready to work harder because regular children who are enrolled in inclusive schools are those that have several disabilities and limitations $[11,12,13]$. Thus, to provide good services in inclusive schools for everyone, it is necessary to adapt the curriculum in some material that is tailored to the abilities and constraints of children with special needs [14].

Hrivnak and Ilahi \& Rose $[15,16]$ emphasized that the curriculum is important to organize the direction and goals of education following the needs of students without ignoring the rights that have not been achieved. Simply stated, the curriculum is an important part of any educational planning that affects the direction and goals of students in educational institutions $[15,17,18]$. Furthermore, Ilahi and Rose [16] explained that inclusive education curriculum uses regular school curriculum (national curriculum) which is modified (improvised) according to the development stage of children with special needs, taking into account the characteristics and level of intelligence.

In a paper written by Mumpuniarti and Cahyaningrum [19], the inclusive learning model requires teachers to serve students with various learning needs. Variation of needs is fairness in life, and the implication is to be fulfilled individually as a part of human rights [20,21]. To meet these demands, teachers require arrangements at each stage of the learning process which consist of adapting strategies and methods and initiating collaboration [22]. In terms of collaboration, students who are more academically capable will mentor the other students. Students who have advanced development in certain areas share their abilities with their friends. The collaboration will build mutual knowledge/skills constructively between students with the help of teachers using various mediations. This is based on the learning theory initiated by Vygotsky [23].

A plethora of studies has investigated the implementation of inclusive education in Indonesia. A study by [24] that analyzed two inclusive schools in Bandung reported that the funding for teachers was still inadequate. Another study [25] looked into 186 supportive environments in Indonesian cities such as Palembang (South Sumatra Province), Solo, Wonogiri, Sukoharjo, Karanganyar, as well as Boyolali (Central Java Province), or rather Makasar (South Sulawesi Province), and found that most educators, particularly special education teachers, did not modify their instructions and were not specifically trained to manage heterogeneous classes. A study by [25] on the 51 inclusive elementary schools in Central Java Province reported that there was no manual of inclusive education management for teachers, especially about the roles, duties, and responsibilities of each teacher. Previous studies have thoroughly examined the implementation of inclusive education in Indonesia, yet there has not been a study that focuses on the implementation of the curriculum and learning model management in inclusive schools.

Based on this context, the researchers believed it was critical to do a study on curriculum creation for learners with disabilities in inclusive schools. This study focuses on inclusive secondary schools since they are regarded as the gold standard of education.

\section{METHOD}

This study was a research development project to create a management model for inclusive secondary schools. Development of research, also known as Educational Research and Development (Educational R\& D). Educational R\&D was a technique for developing and validating educational goods [26]. Furthermore, R\&D may be described as a process or set of actions to create a new product or improve an existing one. The product referred to in this context is not always in the form of hardware (books, modules, learning aids in classrooms and laboratories), but can also be software such as programs for data processing, classroom learning, libraries or laboratories, or models education models, training learning, guidance, evaluation, management, and so on. The research method was carried out in the form of a "cycle", which begins with the investigation of needs and problems that require to be solved with a particular product. This method was applied in two junior high schools from one city in Indonesia.

The research design used in this study was development research by Borg and Gall [26] who stated that research and development were carried out through (1) researching and gathering information, (2) planning a prototype to be developed, (3) developing an initial prototype, (4) conducting a limited trial of the initial model, (5) revising the initial model, (6) conducting a field trial, (7) conducting a product revision, (8) conducting an operational field test, (9) revising the model, and (10) conducting dissemination on to various parties. Moreover, this Borg and Gall model was modified by collaborated with the research development proposed by Thiagarajan [27] namely Define, Design, Develop, and Dissemination.

\section{RESULT AND DISCUSSION}

\subsection{Curriculum Management in Inclusive Schools}

The management of inclusive schools' curriculum becomes a necessity that must always be developed. In curriculum management there are several components namely planning (syllabus and lesson plans), 
implementing, and evaluating. The preparation of the syllabus and lesson plans has also involved a collaborative process between class teachers and special education teachers $[28,29,30]$. The compiled lesson plan also includes a modified lesson plan that is adjusted to the needs and capacity of each child with special needs. This is in line with the concept put forward by the Directorate of Primary Education on Special Education and Special Services [31], namely the preparation of lesson plan for inclusive classes is the same as the lesson plan for regular classes. Moreover, both lesson plans are related to the elements, structure, and process of developing them. Furthermore, to facilitate the implementation of learning arrangements for children with special needs, additional notes are needed in the general lesson plans that have been made by the teacher. The additional notes found in the two cases took the form of making special indicators, making steps for specific core activities, and preparing special assessments.

Based on the findings of the research, the two cases have also prepared lesson plans quite well and fulfill the requirement for relevant information in inclusive schools as defined by the Directorate of Special School Improvement [32], which include: organizing student engagement, planning the institution of materials, determining the strategic approach to the teaching process, planning the procedure of activities of teaching and learning, planning resources and teaching materials, and planning the assessment process that will be applied. Furthermore, these findings duplicate previous studies by $[33,34,35,36]$ who revealed that it is important to modify lesson plans under the character of each child with special needs, as well as adequate learning planning.

The implementation of curriculum management and learning model which were developed in the two schools that were investigated showed that all of them have applied curriculum modifications that are developed according to the abilities of children. With the modified curriculum, every student in both schools gets the same treatment in the learning process. By implementing these, schools tried to facilitate and optimize students' development based on their abilities. Some materials are simplified or even eliminated if it is not following the abilities of the students. In addition, the schools provide facilities in terms of behavioral therapy services, academic therapy, motivational therapy, and the development of interests and talents.

These results are supported with the Implementing Rules and Regulations of Inclusive Education [37], which declare that there are several types of inclusive school curricula available, including (1) national standard curriculum which is intended for children with special needs who have an average of intelligence; (2) accommodative curriculum below national standards which is intended for children with special needs who have below the average of intelligence; and (3) accommodative curriculum above national standard which is intended for children with special needs who have special intelligence and/or a specific talent. This has been applied by the two cases studied. Furthermore, curriculum modification was also carried out with the curriculum alignment model recommended in the General Guidelines for the Implementation of Inclusive Education [37] which was carried out in the form of escalation, duplication, modification, substitution, and omission. The escalation model means that the national standard curriculum is raised in the qualification level of the learning material. The duplication model (imitating / duplicating) means the development of a curriculum for students with special needs by using the national standard curriculum that applies to regular students in general. Modification model means changing to adjust. Substitution model means replacing the contents of the national standard curriculum with other materials. While the omission model (eliminating) means eliminating some / all of the contents of the national standard curriculum. The implementation of curriculum modification in each case becomes the authority of class teachers and special education teachers by continuing to collaborate and getting approval from the school principal.

This finding is consistent with the findings of [25], who conducted a study of 186 inclusive classrooms across several Indonesian cities, including Bandung, Palembang, Solo, Wonogiri, Sukoharjo, Karanganyar, Boyolali, and Makassar, and discovered that more than 56 percent of schools evaluated had transformed the syllabus to apply to learn for children with special needs.

\subsection{Inclusive Schools' Curriculum Implementation}

In implementing the inclusive schools' curriculum there are two main aspects, namely aspects of classroom management and individualized education program (IEP).

\section{A. Classroom Management in Inclusive Schools}

Organizing is a grouping of people, tools, tasks, tasks, authorities, and responsibilities in such a way as to create an organization that can be mobilized as a unitary activity that has been determined [38,39], while organizing learning in inclusive school is carried out by involving the elements that are in the school are the principal, teachers, and special education teachers. All students regardless of their differences are involved in the learning process $[40,41,42]$. Based on the findings the two schools have differences in the implementation of the management of learning model in inclusive schools.

In terms of available class services, both schools have implemented class services in line with the General Guidelines for the Implementation of Inclusive Education [37] and [43] which include: regular classes (full inclusion), regular classes with clusters, regular classes with pull out, regular classes with cluster and pull out, special classes with various integration, and full special classes. As for School One, they implemented 
more forms of class organizing which include: full regular class, the regular class with cluster, the regular class with pull out, and special class. Whereas in School Two, they only implemented full regular class organizing and regular classes with pull out. Furthermore, the process to determine the class is more dynamic in School One, as they involved special education teachers and class teachers, while in School Two this process is solely handled by the headmaster.

This finding is similar to the results of a study by [24] in two inclusive schools in Bandung which reported that collaboration between the principal and special education teachers has not been able to run optimally. As for determining the organization of classrooms, this process should involve class teachers, specific subject teachers, special education teachers, school principals, and other experts. This is in line with the opinion of [44] who revealed that active collaboration between school residents and experts is important in developing and implementing learning for students with special needs in inclusive schools. This also emphasizes the characteristics of inclusive learning management, which involves various sources and support from various parties, including school principals, teachers, and special needs. This is consistent with the results of research by [45] who found the importance of cooperation of all parties involved in the implementation of inclusive education so that learning objectives can be achieved effectively and optimally.

In terms of the learning organization, the application of instructional leadership in School One is more adaptable and could be accessed easily based on the needs of children with special needs, for example, if children with special needs have not been in school for a long period, then children with special needs can accommodate first in a particularly unique class/resource room. Whereas at School Two, the execution of the learning organization is more stringent, with disabled children only going to the source room once a week, unless they are experiencing tantrums or meltdowns, in which case they must be comforted beforehand. Based on the significant differences in the characteristics of children with special needs between one student and other students, learning organization must also be done dynamically to prevent children with special needs from showing problematic behavior and disrupting the learning process. Furthermore, this can also maximize children with special needs' learning opportunities $[46,47,48,49]$. Moreover, previous research by Goodenow \& Wenzel [50] shows that students' attachment to school because of the good implementation of a learning organization can have a positive impact on academic motivation, understanding ability, and good emotional development in participants students especially children with special needs.

B. Individualized Education Program (IEP) and Compensatory Services in Inclusive Schools
The two schools studied have implemented the IEP which was prepared and implemented by special education teachers, in particular, School Two also involved shadow teachers in creating IEP. Furthermore, related to the assessment of the IEP program that has been given, both schools have been able to carry out the IEP assessment according to the assessment schedule predetermined in the IEP plan. If after the children with special needs assessment has not reached the expected goals, the IEP will be repeated by making changes to the method, as well as the learning media that will be used, this is in line with the opinion of $[51,52,53]$ who revealed the importance of good planning before IEP carried out and the process of monitoring and evaluation can be run optimally, and produce the most appropriate follow-up for each child with special needs.

Compensatory services are services for children with special needs tailored to the conditions of the child's disability so that they will get different services. The two schools established compensating services for students with special needs, including leisure activities like music and athletics, along with personality courses, bodybuilding, potty training, and physical therapy. Special education instructors provide compensatory services at School One. while at School Two it is provided by special education teachers with the assistance of a shadow teacher. This is consistent with the results of the interview with the special education teacher at School One as follows:

The special program that I have implemented is selfdevelopment, development motor (bodybuilding), toilet training, and literacy programs. Usually, it is coupled with extracurricular activities, on Saturdays. For the program there is no specific format, I compile it myself, usually also discuss it with special education teachers. So far, I have not developed a structured compensatory service program, and there are still no guidelines yet until now.

Furthermore, as mentioned in the General Implementing Rules and Regulations of Free And compulsory education [37], one of the tasks of special education instructors is to offer replacement services for children with special needs, with compensatory services supplied based upon every child's issues. The two schools still have not implemented compensatory services which directly lead to the barriers experienced by each child with special needs. Compensatory services provided are more incidental and lead to vocational skills in children with special needs, this is not wrong, but the development of compensatory skills is important as it can prevent secondary disruption while strengthening the basic / prerequisite abilities of children with special needs. Additionally, neither school has nor implements Specialized Strategic Development Guidelines. In the lack of Specific Development Guidelines compiled mostly by the Ministry of Education and Culture [31], compensating services are implemented that are unable to function properly, organized, and quantifiable. 


\section{CONCLUSION}

Based on the research that has been carried out, it can be concluded as follows(1) The curriculum management of inclusive classrooms has already been done in both schools according to need, the 4 curriculum development approaches, notably sequencing, reconfiguration, inadvertent, and alternation. These activities were completed in an integrated manner, taking into account the students' requirements and abilities, as well as the learning resources. (2) The implementation of inclusive schools' curriculum management is carried out by 1) an integrated class management model (regular classes with clusters, regular classes with pull-outs, regular classes with clusters and pull-outs, and full special classes) 2) Individualized education plans (IEPs) and compensatory assistance for children with exceptional needs in inclusive schools

\section{REFERENCES}

[1] Manning, M. L., Baruth, L. G., \& Lee, G. L, "Multicultural education of children and adolescents." Taylor \& Francis, 2017.

[2] Smith, W. C., Fraser, P., Chykina, V., Ikoma, S., Levitan, J., Liu, J., \& Mahfouz, J, "Global citizenship and the importance of education in a globally integrated world." Globalization, Societies, and Education, 15(5), 648-665, 2017.

[3] Undang - Undang Republik Indonesia nomor 20 tentang Sistem Pendidikan Nasional. Jakarta. Depdiknas, 2003.

[4] Peraturan Menteri Pendidikan Nasional nomor 70 tentang pendidikan inklusif bagi Peserta Didik yang memiliki kelainan dan memiliki potensi kecerdasan dan / atau bakat istimewa. Jakarta. Depdiknas, 2009.

[5] Baker, B. D., Green III, P. C., \& Ramsey, M. J, "Financing education for children with special needs." In Handbook of leadership and administration for special education (pp. 130-147), Routledge, 2018.

[6] Santoso, H, "Cara memahami dan mendidik anak berkebutuhan khusus." Yogyakarta: Gosyen Publishing, 2012.

[7] Stow, L., \& Selfe, L, "Understanding children with special needs " (Vol. 52). Routledge, 2018.

[8] Baran, J., \& Winzer, M. (2017). "Democratizing education: a case study of inclusive schooling for students with special needs in Poland." Education and Society, 35(2), 5-21, 2017.

[9] Clark, C., Dyson, A., \& Millward, A, "Towards inclusive schools: Mapping the field." In Towards inclusive schools? (pp. 164-178). Routledge, 2018.

[10] Hosshan, H., Stancliffe, R. J., Villeneuve, M., \& Bonati, M. L, "Inclusive schooling in Southeast Asian countries: a scoping review of the literature." Asia Pacific Education Review, 1-21, 2019.
[11] Okyere, C., Aldersey, H. M., \& Lysaght, R, "The experiences of teachers of children with intellectual and developmental disabilities in inclusive schools in Accra, Ghana." Journal of Research in Special Educational Needs, 19(4), 283-294, 2019.

[12] Round, P. N., Subban, P. K., \& Sharma, U, “'I don't have time to be this busy.'Exploring the concerns of secondary school teachers towards inclusive education." International Journal of Inclusive Education, 20(2), 185-198, 2016.

[13] Weiss, S., Muckenthaler, M., Heimlich, U., Kuechler, A., \& Kiel, E, "Teaching in inclusive schools. Do the demands of inclusive schools cause stress?". International Journal of Inclusive Education, 1-17, 2019.

[14] Ballard, S. L., \& Dymond, S. K, "Addressing the general education curriculum in general education settings with students with severe disabilities." Research and Practice for Persons with Severe Disabilities, 42(3), 155-170, 2017.

[15] Hriynak, G. A, “The Increasing Importance of Curriculum Design and Its Implications for Management Educators." Journal of Management Education, 43(3), 271-280, 2019

[16] Ilahi, M. T., \& Rose, K. R, "Pendidikan Inklusif: Konsep \& Aplikasi.” Yogyakarta: Ar-ruzz Media, 2013.

[17] Clarkson, L. M. C., \& Louis, K. S, "Leadership for Curriculum Change: Schools Engaged in "Closing the Gap".” In Learner-Centered Leadership (pp. 111-130). Routledge, 2017.

[18] Huber, S., Tulowitzki, P., \& Hameyer, U, "School leadership and curriculum: German perspectives.' Leadership and Policy in Schools, 16(2), 272-302, 2017

[19] Mumpuniarti, R. S., \& Cahyaningrum, E. S, “Kebutuhan Belajar Siswa Lamban Belajar (Slow Learner) di Kelas Awal Sekolah Dasar Daerah Istimewa Yogyakarta.” Artikel Penelitian. Pendidikan Luar Biasa Fakultas Ilmu Pendidikan Universitas Negeri Yogyakarta, 2011.

[20] D'warte, J. "Students as linguistic ethnographers: Superdiversity in the classroom context." In Super dimensions in globalization and education (pp. 19-35). Springer, Singapore, 2016

[21] Moloney, R., \& Saltmarsh, D, “'Knowing Your Students' in the Culturally and Linguistically Diverse Classroom." Australian Journal of Teacher Education, 41(4), 5, 2016.

[22] Westwood, P, "Inclusive and adaptive teaching: Meeting the challenge of diversity in the classroom." Routledge, 2018 .

[23] Santrock, J. W, “Life Span Development Jilid II.” Jakarta: Airlangga, 2002.

[24] Sunanto, J, "Implementasi pendidikan inklusif di Sekolah Dasar.” Bandung. Pusat Kajian dan Inovasi Pendidikan Sekolah Pasca Sarjana UPI, 2009. 
[25] Yusuf, M., Sunardi, Maman, R., Haryono, "The Development of Inclusive Education Schools." The Journal of Educational Development, 2(2), 155-160, 2011.

[26] Gall, M. D., Borg, W. R., \& Gall, J. P, "Case study research" Educational research: An introduction, 123163,2003

[27] Thiagaradjan, S. D. S, Semmel \& M. I, Semmel, "Instructional Development for Teacher Center of Expectional Children." Minepolish: Indiana University, 1974.

[28] Khoza, S. B, “Can curriculum managers' reflections produce new strategies through Moodlei visions and resources?" South African Journal of Education, 36(4), 19, 2016.

[29] Lee, J. R., \& Lee, H. S, "A Qualitative Case Study of Science Core School Curriculum Management." The journal of Sustainable Design and Educational Environment Research, 16(3), 37-50, 2017.

[30] Nixon, J, "Managing the school curriculum for the new millennium." In Vision and Values in Managing Education (pp. 220-231). Routledge, 2018.

[31] Dikdas, D. P, "Buku Pedoman Progsus." Jakarta: Kemendikbud, 2014.

[32] Direktorat Jenderal Manajemen Pendidikan Dasar dan Menengah, "Pembelajaran dan Pendidikan Penyelenggaraan Pendidikan Inklusi: Model Modifikasi Bahan Ajar." Jakarta: Direktorat Pembinaan Sekolah Luar Biasa, 2007.

[33] Lee, J. E., Lim, W., \& Kim, H. J, "Lesson Planning: How Do Pre-service Teachers Benefit from Examining Lesson Plans with Mathematics Teaching Practices as an Analytical Lens?" Education of Primary School Mathematics, 19(3), 211-222, 2016.

[34] Martin, E. W, "Breakthrough: Federal special education legislation 1965-1981.” Sarasota, FL: Bardolf, 2013.

[35] Nagro, S. A., Fraser, D. W., \& Hooks, S. D, "Lesson planning with engagement in mind: Proactive classroom management strategies for curriculum instruction.” Intervention in School and Clinic, 54(3), 131-140, 2019.

[36] Smith, A., \& Bell, S, "Towards Inclusive Learning Environments (TILE): Developing the 'Roadmap for the Inclusion of Students with Special Educational Needs in Vocational Education and Workplace Settings" Support for Learning, 30(2), 150-160, 2015.

[37] Pedoman Umum Penyelenggaraan Pendidikan Inklusi, Direktorat PPK-LK Pendidikan Dasar, Kementerian Pendidikan dan Kebudayaan: Jakarta 2011, dalam www.scribd.com/doc/pedoman-umum-inklusi

[38] Reynolds, M., \& Vince, R, "Organizing reflection: An introduction." In Organizing reflection (pp. 15-28). Routledge, 2017.

[39] Siagian, S, "Pengantar Administrasi Pembangunan." Gunung Agung, 1983.
[40] Billingsley, B., DeMatthews, D., Connally, K., \& McLeskey, J, "Leadership for effective inclusive schools: Considerations for preparation and reform." Australasian Journal of Special and Inclusive Education, 42(1), 65-81, 2018.

[41] Lyons, W. E., Thompson, S. A., \& Timmons, V, "We are inclusive. We are a team. Let's just do it': commitment, collective efficacy, and agency in four inclusive schools." International Journal of Inclusive Education, 20(8), 889-907, 2016.

[42] Udvari-Solner, A., \& Thousand, J, "Effective Organisational Instructional and Curricular Practices in Inclusive Schools and Classrooms." In Towards inclusive schools? (pp. 147-163). Routledge, 2018.

[43] Garnida, D, "Pengantar pendidikan inklusif." Bandung: Refika Aditama, 2015.

[44] Bubpha, S., Erawan, P., \& Saihong, P, "Model development for inclusive education management: Practical guidelines for inclusive schools." Journal of Education and Practice, 3(8), 223-232, 2012.

[45] Scanlon, D., \& Baker, D, "An accommodations model for the secondary inclusive classroom." Learning Disability Quarterly, 35(4), 212-224, 2012.

[46] Buli-Holmberg, J., \& Jeyaprathaban, S, "Effective practice in inclusive and special needs education." International Journal of Special Education, 31(1), 119-134, 2016.

[47] Evertson, C. M., \& Weinstein, C. S. (Eds.), "Handbook of classroom management: Research, practice, and contemporary issues." Routledge, 2013.

[48] Finkelstein, S., Sharma, U., \& Furlonger, B, "The inclusive practices of classroom teachers: a scoping review and thematic analysis." International Journal of Inclusive Education, 1-28, 2019.

[49] Srivastava, M., de Boer, A. A., \& Pijl, S. J, "Preparing for the inclusive classroom: changing teachers' attitudes and knowledge." Teacher Development, 21(4), 561-579, 2017.

[50] Mansor, A. N., Eng, W. K., Rasul, M. S., Hamzah, M. I. M., \& Hamid, A. H. A, "Effective classroom management." International Education Studies, 5(5), 3542, 2012.

[51] Assjari, M, "Program Pembelajaran Individual. Jakarta: Departemen Pendidikan Nasional, 2005.

[52] Musyoka, M. M., \& Clark, M. D, “Teachers' perceptions of individualized education program (IEP) goals and related services." Journal of Developmental and Physical Disabilities, 29(1), 5-23, 2017.

[53] Ní Bhroin, Ó., King, F., \& Prunty, A, "Teachers' knowledge and practice relating to the individual education plan and learning outcomes for pupils with special educational needs." Reach: Journal of Special Needs Education in Ireland, 29(2), 78-90, 2016. 